\title{
THE IMPACT OF THE ACADEMIC SKILLS PROGRAMME ON PASS RATES IN THE INTRODUCTION TO SOUTH AFRICAN LAW MODULE AT THE SCHOOL OF LAW (PIETERMARITZBURG CAMPUS) OF THE UNIVERSITY OF KWAZULU-NATAL*
}

\section{Introduction}

In the last two decades, the legal profession has frequently criticized the quality of South African law graduates; in particular many have suggested that students are leaving university without the skills necessary to be successful lawyers (Slabbert "Developing a Skills Course for Distance Law Students" 200931 Progressio 46) This has placed pressure on law schools to respond in a variety of ways; including through introducing academic skills development programmes. The University of KwaZulu-Natal's School of Law, Pietermaritzburg, is one such institution which introduced an academic skills programme in 2006. Many reasons have been put forward for the under-preparedness of young law graduates including; firstly, universities are unceasingly having to admit students who are underprepared for academic study (Greenbaum The Undergraduate Law Curriculum: Fitness for Purpose? (Doctoral thesis, University of KwaZulu-Natal 2009)). Secondly, the Baccalaureus Legum (LLB) was transformed from being a two-year postgraduate qualification to the current four-year undergraduate degree. In other words, law students must now complete their legal studies in four rather than five years at university (Greenbaum The Undergraduate Law Curriculum: Fitness for Purpose?). Thirdly, universities are under enormous financial pressure and it is costly to provide sufficient support to students during their studies to compensate for this lack of preparedness. The unintended consequences of all of these changes has been that less wellprepared students must both graduate and acquire the requisite skills to be good lawyers in a shorter period of time thus placing great pressure on them and law teachers.

Universities and tertiary institutions worldwide run academic skills development programmes. These programmes range from narrowly focusing on writing and oral presentation skills to focusing on broader generic study skills that are needed for law students. The University of KwaZulu-Natal's School of Law, Pietermaritzburg, focused its response to academic skills

The authors would like to thank Professor Marita Carnelley, College Dean of Research, University of KwaZulu-Natal, for her invaluable role in the conceptualization of this study and her active encouragement throughout the writing process. 
development around the introduction of a new position, that of Academic Development Co-ordinator (ADC). The first ADC was appointed in 2006. They began by adopting a five-strand approach which aimed at providing: generic skills tutorials, mandatory counselling sessions for at-risk and probation students, embedded writing development interventions in various courses, staff development and special writing tutorials.

In 2010, an academic skills programme was formally integrated into the curriculum of Introduction to South African Law, a first-year module for LLB students. Currently, the programme is still running and consists of a weekly session with the ADC. These are held in lecture-style sessions dealing with: time management, making the most of lectures, learning styles, test preparation, academic/legal reading, summarizing, answering legal problemtype questions, essay writing, case reading, reading legal and journal articles. The "Time Management" session teaches students to take control of their time and the importance of doing detailed planning for each day. They have to set out a timetable for the week, identifying fixed commitments and free time, with the aim of allocating tasks throughout the day and then inculcating this as a daily habit. "Making the most of Lectures" focuses on note taking (using the Cornell and other methods). "Learning Styles" explores what the student's primary learning style is by going through a questionnaire. Identifying the learning style as either audio, visual or kinesthetic helps the student to study using their strengths. "Test Preparation" covers the cognitive, physical and emotional aspects of preparation, eg, getting the balance right between study, exercise, nutrition and sleep. "Academic Reading" deals with the necessity of learning how to unpack academic text - this session incorporates pre-reading techniques, such as activating prior knowledge. "Answering a Legal Problem Question" takes students through a scenario and using the FIRAC (facts, issue, ratio, application, conclusion) method they learn to answer the problem question. "Essay Writing" touches on the essential features of a legal essay. In the "Case Reading" session the students are shown a strategy for reading cases - looking at the necessity of skimming the case, noting the citation, headnote, flynote etcetera. They are taught the importance of identifying the issue and the ratio. Lastly, "How to Read a Journal Article" introduces the students to journals and how one should tackle reading an article. Student Support (a student counselling and development service in the School) assists with some of the sessions including those dealing with "How to be a Successful Law Student", "Stress Management", "Study Groups" etcetera. All the lecture material is contained in a manual which is distributed to students at the start of the semester. Although there is no formal assessment for the course, students have to hand in set tasks. Lecture attendance is compulsory and a register is taken at every lecture. Students who do not attend lose their Duly Performed certificate (DP) and are prohibited from writing the exam.

Six years after formally integrating the academic skills programme into Introduction to South African Law it needs to be asked: "Has it had a positive impact on student success?" This is obviously a complex question which depends on how one would measure success. This note is an exploratory one which reports on a small quantitative and qualitative study undertaken 
by the School of Law (Pietermaritzburg campus) at the University of KwaZulu-Natal during 2015. The study used pass rates in the Introduction to SA Law module as a proxy maker for student success. It also obtained student perceptions of the course to review its relevance and effectiveness and finally, it reviewed its content against a scale of factors which could predict the ability of a student to succeed which had been developed elsewhere.

\section{Academic skills programmes as a means of enhancing the quality of law students}

The dictionary defines "skill" as being "the ability, coming from one's knowledge, practice, aptitude, etcetera, to do something well" (On-line dictionary http://www.dictionary.com/browse/skill (accessed 2016-05-27)), whilst the term "academic" is defined as amongst others as "pertaining to areas of study that are not primarily vocational or applied, as the humanities or pure mathematics" (On-line dictionary http://www.dictionary.com/browse/ academic (accessed 2016-05-27)). One would assume that the ordinary meaning of academic skills would therefore be the enhancement of knowledge, practice and aptitude in the particular field of study. In the context of the LLB one would assume this to mean that academic skills would focus on the skills needed to become a successful lawyer.

Much of the literature around Academic Skills focuses on writing skills. Authors such as MacVaugh, Jones and Auty ("Implicit, Stand-alone or Integrated Skills Education for Undergraduates: A Longitudinal Analysis of Programme Outcomes" 201438 Journal of Further and Higher Education 755), however, define academic skills very broadly as being both what would be considered traditional academic skills and the inter-personal skills needed to be an effective member of a workplace. Their definition is that academic skills include "clear writing, oral presentation, teamwork and team-building, problem identification, argumentation and interpersonal skills". This definition resonates to some extent with the outcomes of a study undertaken by Ngidi ('Students' and lecturers' perceptions of some factors influencing students' academic success or failure at a historically black university in South Africa" 200721 South African Journal of Higher Education 717).

The literature shows further that several studies have been done on the most effective means of teaching skills. MacVaugh, Jones and Auty, found that "The introduction of an integrated approach to the teaching of academic skills has increased the performance outcomes of learners in the business and management programme in first, second and third year modules ..." (MacVaugh, Jones and Auty 201438 Journal of Further and Higher Education). Furthermore, their paper concludes "the present study provides empirical data to support the earlier research suggesting that for skills to succeed, they should be taught in an integrated and contextual manner ..." and "robust evidence of the correlation between participation in an integrated skills course and success in other modules in a degree programme ..." (MacVaugh, Jones and Auty 201438 Journal of Further and Higher Education). 
There is also literature on the content of academic skills programmes. For example, Bond University's Legal Skills course (Wolski "Why, How and What to Practice: Integrating Skills Teaching and Learning in the Undergraduate Law Curriculum" 200252 Journal of Legal Education 287) contains components such as "Legal Research and Analysis", "Information Technology", "Negotiation and Dispute Resolution", etcetera (Wolski 2002 52 Journal of Legal Education).

\section{This study}

\section{Aims}

The study aimed at reviewing the School's academic skills programme with a view to assessing whether (a) it was having an impact on the pass rate in the Introduction to South African law module, (b) students perceived it to be of value in promoting "success", (c) students were satisfied with the way in which the skills programme was being run at the time of its implementation and (d) the current content of the programme measures up against the top factors that were identified by Ngidi as enhancing student success.

\section{Methodology}

The study used a mixed-methods approach which included qualitative, quantitative and record review methodologies.

Firstly, a baseline review was done of the pass rates of the course over a ten-year period (from 2005-2014). In other words, the pass rates from five years before the intervention and five years after. Exam pass rates were obtained from the Division of Management Information (DMI), now known as Institutional Intelligence (II), which is part of Information Communications Services (ICS). The average pass rate per year was worked out.

Secondly, students from the 2015 Administrative Law (a final year LLB module) class were invited to participate in an interview with the ADC to discuss their perceptions of the academic skills programme that they had undergone when they were in the first year of the LLB. The only inclusion criteria were; willingness to participate and they must have done Introduction to South African Law in 2011 or 2012. Approximately 50 students were individually telephoned and invited to participate. Nineteen students agreed and attended a semi-structured interview. Two interviews were excluded at the analysis phase as the students had not attended the skills programme. Therefore, seventeen interviewees formed part of the final cohort. Notes were taken during the interviews and analyzed on a thematic basis.

Thirdly, the annual student evaluation of the academic skills programme undertaken in 2012 was re-evaluated. 105 students were registered for the Introduction to South African Law module in 2012 and 65 participated in the course evaluation.

Fourthly, the nine criteria identified by Ngidi in his "success scale" were used as benchmarks of the content of a skills programme and a desk review 
was done of the extent to which the current skills curriculum addresses these content areas.

\section{Overview of the Ngidi study}

In this study Ngidi, using a structured questionnaire, asked 20 staff and 201 students doing a Bachelor of Education $(B(E d)$ ) to rank (in order of importance) the factors that could contribute to student success at university. The study took place at the University of Zululand (Ngidi 200721 South African Journal of Higher Education 717).

On the basis of the data collected he was able to develop a list of 34 factors which were ranked in a "success scale". Interestingly, there was a strong correlation between the success factors identified by staff and students but a very weak correlation between the views of staff and students on factors that could lead to failure at university (Ngidi 200721 South African Journal of Higher Education).

The seven top factors identified by lecturers were: self-discipline, effective study methods, family support, appropriate balance between academic commitments and social life, self-motivation, ability to work independently and interest in the course; whilst the top seven factors for students were: self-discipline, self-confidence, interest in the course, self-motivation, family support, timely and regular examination preparation and appropriate choice of course of study. If these factors get clustered, it appears that they fall into four main groups; academic skills, personal development skills, personal motivation and structural factors. Tables 1 and 2 below show that both lecturers and students saw personal development skills as being the most useful. They also both identified one structural issue, family support as being critical with staff ranking this third and students fifth respectively. Interestingly, each group only identified one academic type skill as being important; study methods (staff) and timely exam preparation (students) (Ngidi 200721 South African Journal of Higher Education).

Table 1: Types of skills/values that were identified as being most useful by Lecturers in Ngidi's study

\begin{tabular}{|c|c|c|c|}
\hline $\begin{array}{l}\text { Academic } \\
\text { Skills }\end{array}$ & $\begin{array}{l}\text { Personal } \\
\text { Development Skills }\end{array}$ & $\begin{array}{l}\text { Personal } \\
\text { Motivation }\end{array}$ & $\begin{array}{l}\text { Structural } \\
\text { Factors }\end{array}$ \\
\hline $\begin{array}{ll}\text { - } & \text { Study } \\
& \text { methods }\end{array}$ & $\begin{array}{l}\text { Balanced life } \\
\text { - Work } \\
\text { independently }\end{array}$ & $\begin{array}{ll}\text { - } & \text { Self-discipline } \\
\text { - } & \text { Self- } \\
\text { motivation } \\
\text { - } \\
\text { Interest in } \\
\text { course }\end{array}$ & $\begin{array}{ll}\text { - } & \text { Family } \\
& \text { support }\end{array}$ \\
\hline
\end{tabular}




\section{Table 2: Types of skills/values that were identified as being most useful by Students in Ngidi's study}

\begin{tabular}{|c|c|c|c|}
\hline $\begin{array}{l}\text { Academic } \\
\text { Skills }\end{array}$ & $\begin{array}{l}\text { Personal } \\
\text { Development Skills }\end{array}$ & $\begin{array}{l}\text { Personal } \\
\text { Motivation }\end{array}$ & $\begin{array}{l}\text { Structural } \\
\text { Factors }\end{array}$ \\
\hline & - Self confidence & $\begin{array}{ll} & \text { Self-discipline } \\
\text { - } & \text { Self- } \\
\text { motivation } \\
\text { - } & \text { Regular and } \\
\text { timely exam } \\
\text { preparation } \\
\text { - Appropriate } \\
\text { choice of } \\
\text { course }\end{array}$ & $\begin{array}{ll} & \text { Family } \\
& \text { support }\end{array}$ \\
\hline
\end{tabular}

In his conclusion Ngidi submitted that an understanding of an agreement between staff and students on the factors contributing to success or failure was important to inform future interventions at South African universities (Ngidi 200721 South African Journal of Higher Education 717).

\section{Ethical approval}

Ethical approval for the study was obtained from the Social Health Research Ethics Committee (SHREC) at the University of KwaZulu-Natal. The approval reference number is HSS/0983/015.

\section{Limitations}

This study has been limited by a number of factors including, firstly, the measurement of student success was any increase or decrease in pass rates for the first-year module. This is a very crude form of measurement as there are many potential variables that could have an impact on pass rates. The qualitative interviews were also only undertaken with LLB students even though many non-LLB students do join the LLB programme as postgraduates.

\section{$4 \quad$ Findings}

We were able to make the following findings from the study:

(i) The LLB pass rates in Introduction to South African Law increased following the introduction of the academic skills programme

The 2005 pass rate for Introduction to South African Law was 75\%. The 2009 pass rate was $67 \%$. The average for these 5 years was $76.8 \%$. The 2010 pass rate was $78 \%$, whilst the 2014 pass rate was $89 \%$. The average 
of these 5 years was $83 \%$. The average increase in pass rate was a moderate $6.2 \%$.

\section{Table 3: Pass rates in Introduction to South African Law 2005-2014}

\begin{tabular}{|l|l|l|l|l|l|l|l|l|l|}
\hline $\mathbf{2 0 0 5}$ & $\mathbf{2 0 0 6}$ & $\mathbf{2 0 0 7}$ & $\mathbf{2 0 0 8}$ & $\mathbf{2 0 0 9}$ & $\mathbf{2 0 1 0}$ & $\mathbf{2 0 1 1}$ & $\mathbf{2 0 1 2}$ & $\mathbf{2 0 1 3}$ & $\mathbf{2 0 1 4}$ \\
\hline $\mathbf{7 5} \%$ & $72 \%$ & $88 \%$ & $82 \%$ & $67 \%$ & $78 \%$ & $\mathbf{7 9} \%$ & $90 \%$ & $\mathbf{7 9} \%$ & $89 \%$ \\
\hline
\end{tabular}

(ii) LLB students perceived the programme to be broadly of value

The Student Support evaluation of the 2012 group showed that over $90 \%$ of the students reported that they felt that they had benefitted from these workshops. Three and a half years later student perceptions of the value of the academic skills programme remained constant with $91 \%$ having found the programme to be positive/useful, whereas only $9 \%$ found them not worthwhile. Key comments included the view that skills changed the way they approached their studies.

"Skills has changed my mindset" (2012 Evaluation)

Others noted that specific very practical life skills were found to be the most useful:

"Time management was the most important for me." (2012 Evaluation)

"I have learned a lot, especially time management, legal reading and FIRAC

(Facts, Issue, Ratio, Application and Conclusion)." (2012 Evaluation)

Some saw the skills as being valuable beyond their degree:

"All useful for our law career." (2012 Evaluation)

Students interviewed were asked if they would recommend the academic skills programme to others. All the responses were positive.

"Yes, it prepares you for what is ahead, especially time management and writing skills." (Participant 3)

"Yes, it is a good foundation ... you'll know how to manage your cases and manage your time." (Participant 2)

Interestingly, generic practical skills such as time-management were perceived to be the most useful by many of the students.

(iii) Most LLB students saw that the law-specific academic skills as having contributed to their academic success

Most students found law specific skills to be of real value:

"Yes, it introduces you to Law - gives you skills how to tackle questions and how to deal with Law issues." (Participant 17) 
How to answer a legal problem-type question was identified as being particularly useful:

"FIRAC was helpful in certain modules ..." (Participant 1)

"Summarizing and FIRAC ..." (Participant 4)

"[c]ase reading ... and FIRAC." (Participant 9)

A smaller number saw general academic skills to be the most valuable:

"Skills helps, especially time management." (Participant 17)

\section{(iv) The academic skills programme had unintended social benefits}

The academic skills programme was identified as being a less pressurized, non-threatening environment, in which active participation was encouraged. This was a very different approach to that taken in most of their other substantive modules. Students noted that this helped with personal development:

"[h]elped to settle in the Law degree." (Participant 6)

"Helps you transition from high school to first year." (Participant 10)

"Generally it taught me how to manage myself as a person." (Participant 16)

(v) The interactive methodology and the environment created in the class was found to be beneficial to personal growth

Students stated that they felt able to participate in discussions as their opinions were respected:

"[d]idn't feel as serious as other modules ... I was asked to participate ... spoke for the first time in class." (Participant 12)

"[p]eople's opinions counted." (Participant 14)

"Academic Skills were classes that you looked forward to going to - not heavy, but creative." (Participant 3)

"[s]pace to relax, not too much pressure ... informed you about studying." (Participant 13)

(vi) The academic skills programme addressed many of the skills identified by both staff and students in Ngidi's study of the factors that underpin student success

When reviewing the contents of the academic skills programme against Ngidi's list of the most significant criteria of success, 6 of the combined factors mentioned above (lecturers and students' perceptions) form part of the skills curriculum. Furthermore, out of Ngidi's 34 factors, 14 of them are explicitly integrated and 3 are implicit in the academic skills sessions (including the sessions facilitated by Student Support). See Table 4 below. 
Table 4: Assessment of whether the School of Law's Academic Skills programme is addressing factors identified in Ngidi's success scale

\begin{tabular}{|c|c|c|c|}
\hline $\begin{array}{l}\text { Factors } \\
\text { identified as } \\
\text { being critical to } \\
\text { student success } \\
\text { (ranked in order) }\end{array}$ & $\begin{array}{l}\text { Identified by } \\
\text { lecturers }\end{array}$ & $\begin{array}{l}\text { Identified by } \\
\text { students }\end{array}$ & $\begin{array}{l}\text { Manner } \\
\text { included in } \\
\text { curriculum }\end{array}$ \\
\hline Self-discipline & $\mathrm{X}$ & $\mathrm{X}$ (first factor) & $\begin{array}{l}\text { Time } \\
\text { management } \\
\text { Goal setting }\end{array}$ \\
\hline $\begin{array}{l}\text { Effective study } \\
\text { methods }\end{array}$ & $\mathrm{X}$ & & $\begin{array}{l}\text { Learning } \\
\text { styles } \\
\text { Academic } \\
\text { reading } \\
\text { FIRAC }\end{array}$ \\
\hline Family support & $\mathrm{X}$ & $\mathrm{X}$ (fifth factor) & \\
\hline $\begin{array}{l}\text { Appropriate } \\
\text { balance between } \\
\text { academic } \\
\text { commitments and } \\
\text { social life }\end{array}$ & $X$ & & $\begin{array}{l}\text { Time } \\
\text { management }\end{array}$ \\
\hline Self-motivation & $\mathrm{X}$ & $\mathrm{X}$ (fourth factor) & $\begin{array}{l}\text { Learning } \\
\text { Styles } \\
\text { (Student } \\
\text { Support) }\end{array}$ \\
\hline $\begin{array}{l}\text { Ability to work } \\
\text { independently }\end{array}$ & $\mathrm{X}$ & & $\begin{array}{l}\text { University } \\
\text { Survival Skills } \\
\text { (SS) }\end{array}$ \\
\hline $\begin{array}{l}\text { Interest in the } \\
\text { course }\end{array}$ & $\mathrm{X}$ & $\mathrm{X}$ (third factor) & $\begin{array}{l}\text { University } \\
\text { Survival Skills } \\
\text { (SS) }\end{array}$ \\
\hline Self confidence & & $\begin{array}{l}X \text { (second } \\
\text { factor) }\end{array}$ & $\begin{array}{l}\text { The Power of } \\
\text { Study Groups } \\
\text { (SS) }\end{array}$ \\
\hline $\begin{array}{l}\text { Timely and } \\
\text { regular } \\
\text { examination } \\
\text { preparation }\end{array}$ & & $\mathrm{X}$ (sixth factor) & $\begin{array}{l}\text { Exam } \\
\text { preparation }\end{array}$ \\
\hline $\begin{array}{l}\text { Appropriate } \\
\text { choice of course } \\
\text { of study }\end{array}$ & & $\begin{array}{l}\text { X (seventh } \\
\text { factor) }\end{array}$ & $\begin{array}{l}\text { University } \\
\text { Survival Skills } \\
\text { (SS) }\end{array}$ \\
\hline
\end{tabular}

The only factor not specifically covered, though alluded to, is "family support". Table 5 below shows how the curriculum is spread across the 4 key areas identified in the Ngidi study. 
Table 5: The extent to which the skills programme addresses academic, personal development, personal motivation skills and structural factors

\begin{tabular}{|c|c|c|c|}
\hline $\begin{array}{l}\text { Academic } \\
\text { skills }\end{array}$ & $\begin{array}{l}\text { Personal } \\
\text { development } \\
\text { skills }\end{array}$ & $\begin{array}{l}\text { Personal } \\
\text { motivation }\end{array}$ & $\begin{array}{l}\text { Structural } \\
\text { factors }\end{array}$ \\
\hline $\begin{array}{ll} & \text { Learning } \\
\text { styles } \\
\text { Academic } \\
\text { reading } \\
\text { - Exam } \\
\text { preparation } \\
\text { - } & \text { FIRAC }\end{array}$ & $\begin{array}{ll}\text { - } & \text { University } \\
\text { Survival Skills } \\
\text { (SS) } \\
\text { - The Power of } \\
\text { Study Groups } \\
\text { (SS) }\end{array}$ & $\begin{array}{ll}\text { Time } \\
\text { management } \\
\text { Goal setting }\end{array}$ & $\begin{array}{l}\text { Not } \\
\text { addressed } \\
\text { directly, } \\
\text { referrals to } \\
\text { Student } \\
\text { Support }\end{array}$ \\
\hline
\end{tabular}

\section{Discussion}

This study showed that the academic skills programme had an impact on the pass rate in the Introduction of South African Law module. It can be assumed that this means that teaching academic skills as part of this course is a factor in improving the academic competence of law students. Here, it is assumed that teaching students basic academic reading and exam preparation skills is assisting them in improving their ability to pass the exam. Interestingly, whilst the BEd students in Ngidi's studies did not identify any pure academic skills in their top seven factors of success, the students in this study seemed to find the legal academic skills, such as how to answer a legal problem question using the FIRAC method very helpful.

The personal development and motivation skills were highly valued by the students and were generally seen as being as important as the academic skills. In many respects, this confirms that academic skills need to viewed very broadly. Ngidi's study of the factors that enhance the possibility of students being successful found that there were a range of factors, with pure academic skills being rated quite low. Inter-personal and personal development skills got a far higher rating by both academic staff and students.

The academic skills programme seemed to have some unintended consequences - students indicated enhanced personal development through the use of interactive methodologies and a class environment that promoted participation. Many students viewed it as a "safe place" which enhanced selfconfidence.

An interesting issue to emerge from this study was that a significant number of students saw the academic skills programme as a very useful bridge between school and university. It appears that for these students the programme helped them adapt to the different demands of university life at both a personal and academic level. Again, this resonates well with Ngidi's work which identified a number of personal attributes which are essential for success at university including; self-discipline, a balanced life, self- 
motivation and an ability to work independently. Currently, the programme content is well balanced and addresses academic, personal development and personal motivation skills. Given the student feedback it appears that this approach should be retained. It may also reflect that the collaboration with Student Support, who provide the lectures on personal development and personal motivation, is a key reason for the success of the programme.

\section{Conclusion and recommendations}

The issue this paper set out to explore is complex, but academic skills will have a place in South African universities, as long as students continue to arrive under-prepared for their undergraduate studies. It is hoped that the results of this small, exploratory study will open up further debate about the content, placement and nature of academic skills programmes. This study highlights three main issues: academic skills programmes improve pass rates, and secondly, this Law school's academic skills programme is perceived to be of value to students at an academic and personal level. Thirdly, academic skills programmes need to approach capacity development broadly through addressing academic and personal development/motivation needs in order to enhance the ability of students to cope with the rigors of the LLB.

A further study is recommended, where students at the same School of Law are tracked from the commencement of their undergraduate degree through to completion and their performance in terms of grades is examined in greater detail. Work is also required within the law profession to establish the areas in which they believe that students are lacking in skills so that the course can be adapted to meet these needs.

Erica Wille

University of KwaZulu-Natal, Pietermaritzburg

Ann Strode

University of KwaZulu-Natal, Pietermaritzburg 